\title{
KINERJA SKEMA PEMBERIAN TANDA AIR PADA CITRA DIGITAL BERBASIS KOMPUTASI NUMERIK
}

\author{
Endina Putri Purwandari ${ }^{1}$, Diyah Puspitaningrum ${ }^{2}$, Muhamad Yose Sastra ${ }^{3}$ \\ 1,2,3 Program Studi Teknik Infomatika, Fakultas Teknik, Universitas Bengkulu. \\ Jl. WR. Supratman Kandang Limun Bengkulu 38371A INDONESIA \\ (telp: 0736-341022; fax: 0736-341022) \\ ${ }^{1}$ endinaputri@unib.ac.id \\ ${ }^{2}$ diyahpuspitaningrum@gmail.com \\ ${ }^{3}$ muhamadyose@ymail.com
}

\begin{abstract}
Abstrak: Penduplikasian citra digital sangatlah merugikan bagi pemilik aslinya. Salah satu solusi yang diusulkan adalah pemberian tanda air pada citra digital tersebut. Penelitian ini bertujuan untuk mengimplementasikan skema pemberian tanda air pada citra digital dengan berbasis komputasi numerik (SVD - Singular Value Decomposition). Citra masukan yang digunakan terdiri dari 10 buah citra berukuran $512 x 512$ dengan format *.jpg dan *.png. sebagai citra tanda air digital menggunakan citra logo Universitas Bengkulu. Skema yang diusulkan adalah dengan menyisipkan citra masukan dengan citra tanda air logo UNIB, kemudian dilakukan ekstraksi. Citra yang telah diberikan tanda air digital akan diberikan tiga macam serangan, berupa pemberian: (1) noise 15\% dan 20\%; (2) kompresi JPEG 5\%, 15\%, dan 25\%; (3) pengkaburan radius 2 piksel dan 3 piksel. Hasil eksperimen menunjukkan bahwa skema ini dapat memberikan hasil yang optimal untuk penyisipan tanda air citra digital, dan berhasil mengekstraksi kembali tanda air digital berupa logo Universitas Bengkulu walaupun telah melalui serangan.

Kata kunci : tanda air, citra digital, komputasi numerik, ekstraksi, SVD.
\end{abstract}

Abstract: This paper presents a watermarking scheme technique for preventing digital image duplication using numeric computation method (SVD - Singular Value Decomposition). Input images consist of 10 digital images with size of $512 \times 512$ pixels all in *.jpg and *.png. Logo University of Bengkulu is used as digital watermark image. The proposed scheme is: inserting an input image with watermark logo, then extract the watermarked image. Each watermarked images was attacked with: (1) noise 15\% and 20\%; (2) JPEG compression 5\%, 15\%, and 25\%; and (3) blurring radius 2 pixels and 3 pixels. Experiments show that the sceme can provide optimal results for inserting watermark image, and then extracting the logo of digital watermark eventhough the watermarked images are attacked.

Keywords: watermark, digital image, numeric computation, ekstraction, SVD.

\section{PENDAHULUAN}

Watermarking merupakan suatu teknik penyembunyian data atau informasi rahasia ke dalam suatu data lainnya untuk ditumpangi (biasanya disebut dengan host data), dimana orang tidak menyadari kehadiran adanya data tambahan pada host-nya [1]. Jadi seolah-olah tidak ada perbedaan antara host data sebelum dan sesudah proses watermarking. Ada beberapa teknik watermarking yang digunakan yaitu teknik watermarking yang bekerja pada domain spasial dan yang bekerja pada domain transformasi frekuensi. Pada domain spasial salah satunya adalah metode Singular Value Decomposition (SVD) dan LSB. Sedangkan pada domain transformasi frekuensi ada beberapa transformasi, diantaranya seperti: Discrete Wavelete Transform (DWT), Discrete Fourier Transform (DFT), dan Discrete Cosine Transform (DCT).

Trunojoyo [2] menggunakan teknik watermaking dalam domain wavelet untuk proteksi kepemilikan pada data citra medis. Tyas [3] mengusulkan skema watermarking berbasis SVD dan kuantisasi dengan mengeksplorasi matriks nilai singular untuk menyisipkan watermark. Mekanisme dasar yang digunakan adalah kuantisasi 
koefisien terbesar pada matriks nilai singular dengan sebuah nilai konstan yang disebut koefisien kuantisasi.

Basaruddin [4] melakukan penelitian terhadap skema pemberian tanda air (watermark) pada video digital berbasis DWT-SVD dengan detektor semiblind. Penyisipan blok tanda air yang berbeda pada masing-masing video akan mengubah intensitas frame secara bervariasi. Perbedaan pengaruh ini bergantung pada histogram citra dan sebaran koefisien diagonal tiap kanal frame. Robustness tanda air pada skema di tentukan oleh pemilihan ukuran blok citra yang akan di sisipkan. Semakin kecil ukuran blok maka tanda air yang diekstrak akan mempunyai kualitas visual lebih bagus. Semakin sedikit informasi yang disisipkan ke dalam subband diagonal, makin sedikit koefisien diagonal yang berubah. Sehingga saat rekonstruksi oleh inverse-DWT, hanya sedikit blok tanda air yang berubah. Tetapi jika blok citra yang disisipkan makin besar, maka makin banyak informasi tanda air yang hilang akibat rekonstruksi tersebut.

Pada teknik watermark dengan metode Singular Value Decomposition penyisipan umumnya dilakukan pada nilai-nilai singular berdasarkan pertimbangan bahwa nilai singular tidak akan mengalami perubahan signifikan jika terjadi sedikit gangguan pada citra [5]. Metode SVD merupakan teknik yang digunakan untuk merubah matriks citra menjadi matriks SVD dengan cara mendekomposisikannya untuk mendapatkan nilai singular dari citra.

\section{LANDASAN TEORI}

\subsection{Citra Digital}

Citra atau image merupakan istilah lain untuk gambar. Data atau informasi tidak hanya disajikan dalam bentuk teks akan tetapi bisa juga berupa citra. Citra digital adalah citra yang dapat diolah oleh komputer. Data berupa citra mempunyai karakteristik yang berbeda dengan bentuk data yang lainnya, yakni banyak informasi yang dapat diambil dari sebuah citra.

Secara matematis citra merupakan suatu fungsi intensitas cahaya pada bidang 2-dimensi sehingga dapat disimbolkan dengan $f(x, y)$, dengan $(x, y)$ merupakan titik koordinat pada bidang 2-dimensi dan $f(x, y)$ merupakan nilai intensitas cahaya pada titik tersebut. Simbol $x, y$ dan $f(x, y)$ bernilai diskrit [6].

\subsection{Tanda Air Digital}

Watermarking memanfaatkan kekurangankekurangan sistem indra manusia seperti mata dan telinga. Jadi watermarking merupakan suatu cara untuk penyembunyian atau penanaman data atau informasi tertentu (baik berupa catatan umum maupun rahasia) ke dalam suatu data digital lainnya, tetapi tidak diketahui oleh indra manusia (baik indra penglihatan atau indra pendengaran), mampu menghadapi proses-proses pengolahan sinyal digital yang tidak merusak kualitas data yang di-watermark sampai pada tahap tertentu. Data terwatermark tersebut harus tahan terhadap seranganserangan baik secara sengaja maupun tidak sengaja untuk menghilangkan data watermark yang terdapat di dalamnya.

\subsection{Singular Value Decomposition (SVD)}

Metode Singular Value Decomposition (SVD) adalah salah satu teknik dalam basis komputasi numerik yang digunakan untuk "mendiagonalkan” matriks. Dalam sudut pandang pengolahan citra, singular value dari suatu citra memiliki keuntungan stabilitas yang baik, dimana ketika ada sedikit gangguan diberikan pada citra tersebut, singular value tidak berubah secara signifikan. Keuntungan lain adalah ukuran matriks dari 
transformasi metode SVD tidak tetap dan dapat berupa persegi. Kemudian singular value mengandung informasi properti persamaan linear citra.

Suatu matriks misalkan dinamai matriks $A$ dengan nilai eigen dari matriks $A^{T} A$ yaitu $\lambda_{i}$ untuk setiap $1 \leq i \leq n$ dengan $n$ yaitu banyak nilai eigen, maka nilai singular matriks $A$ yaitu $\sigma i=\sqrt{\lambda_{i}}$ dan $v_{i}$ merupakan vektor eigen matriks $A^{T} A$ yang bersesuaian dengan nilai $A^{T} A$.

Secara umum algoritma Singular Value Decomposition (SVD) adalah sebagai berikut [4]:

1. Dibentuk matriks $A^{T} A$ dengan nilai eigen $\lambda_{i}$ untuk setiap $1 \leq i \leq n$ maka nilai singular matriks $A^{T} A$ yaitu $\sigma i=\sqrt{\lambda_{i}}$

2. Dibentuk matriks diagonal $S=$

$$
\left[\begin{array}{ccc}
\sigma_{1} & \cdots & 0 \\
\vdots & \ddots & \vdots \\
0 & \cdots & \sigma_{n}
\end{array}\right]
$$

3. Dicari himpunan vektor eigen dari matriks $A^{T} A$ misalkan $\left\{v_{1}, v_{2}, \ldots v_{n}\right\}$ merupakan vektor-vektor eigen matriks $A^{T} A$ dengan $v_{i}$ merupakan vektor eigen yang bersesuaian dengan nilai $\lambda_{i}$

4. Dibentuk matriks orthogonal $V=$ $\left[v_{1}, v_{2}, \ldots v_{n}\right]$

5. Dibentuk himpunan vektor $U=$ $\left\{\left[u_{1}, u_{2}, \ldots u_{n}\right\}\right.$ dengan $u_{1}=\frac{1}{\sigma_{i}}$

A $\mathrm{v}_{\mathrm{i}}$ untuk setiap $1 \leq i \leq n$

6. Dibentuk matriks orthogonal $U=$

$\left[u_{1}, u_{2}, \ldots u_{n}\right]$

7. Bentuk dekomposisi SVD $A=U S V^{T}$

Nilai $\sigma_{1} \ldots \sigma_{n}$ dari $S$ disebut nilai-nilai singular dari $A$, kolom-kolom dari $U$ merupakan vektorvektor singular kiri dari $A$ dan kolom-kolom dari $V$ merupakan Vektor-vektor singular kanan dari $A$. Jika $A$ adalah sebuah citra maka pengubahan sedikit pada nilai-nilai singular tidak mempengaruhi kualitas citra dan nilai-nilai singular tidak berubah banyak setelah citra diserang [3]. Setelah citra $A$ diproses menjadi matriks SVD, untuk menjadikan citra $A$ menjadi citra yang dengan watermark dibutuhkan adanya kunci watermark. Kunci yang akan dibangkitkan oleh penulis menggunakan pembangkit pseudorandom yaitu pseudorandom dari aturan 2D.

\subsection{Parameter Kinerja Watermarking}

Parameter pengukuran kinerja watermarking menggunakan perhitungan Peak Signal to Noise Ratio (PSNR). PSNR adalah perbandingan antara nilai maksimum dari sinyal yang diukur dengan besarnya derau yang berpengaruh pada sinyal tersebut [7]. PSNR biasanya diukur dalam satuan decibel(dB). PSNR digunakan untuk mengetahui perbandingan kualitas citra cover sebelum dan sesudah disisipi watermark. Untuk menentukan nilai PSNR, terlebih dahulu harus ditentukan nilai MSE. MSE adalah nilai error kuadrat rata-rata antara citra asli dengan citra hasil manipulasi. Nilai PSNR yang lebih tinggi menyiratkan kemiripan yang lebih erat antara citra asli dengan citra hasil rekonstruksi. PSNR didefinisikan sebagai :

$$
P S N R=10 \cdot \log _{10}\left(\frac{M A X_{I}^{2}}{M S E}\right)
$$

Dengan Mean Square Error (MSE) sebagai berikut:

$$
M S E=\frac{1}{m n} \sum_{i=0}^{m-1} \sum_{j=0}^{n-1}[I(i, j)-K(i, j)]^{2}
$$

Dimana :

$m, n \quad=$ Dimensi dari citra

$I(i, j)=$ Menyatakan citra asli.

$K(i, j)=$ Menyatakan citra hasil. 


\section{METODOLOGI PENELITIAN}

Data yang digunakan pada penelitian ini terdiri dari 10 (sepuluh) citra masing-masing berukuran 512 x 512 piksel, berformat .*jpg dan *.png. Sedangkan citra sisipan adalah citra berwarna logo Universitas Bengkulu. Selanjutnya citra yang telah disisipi tanda air akan diberikan serangan dengan pengkaburan (blurring), noise, dan kompresi. Perangkat keras (Hardware) yang digunakan dalam membangun aplikasi adalah komputer dengan Processor Intel Core I, DDRAM3 2 GB, Harddisk 500 GB, dan Monitor LCD. Perangkat lunak yang digunakan adalah: Sistem Operasi Windows Seven Ultimate, dan bahasa pemprograman MatLab R2010A.

\section{IV.EKSPERIMEN}

Pada penelitian ini akan dibangun skema pemberian tanda air digital dengan menggunakan komputasi numerik melalui metode Singular Value Decomposition (SVD). Skema yang dibangun diharapkan juga mampu mengidentifikasi citra watermark dari ter-watermark ketika mendapat serangan blur, noise, dan kompresi.

Skema pemberian tanda air digital berbasis komputasi numerik ini terbagi menjadi dua tahapan, yaitu penyisipan dan ekstraksi.

a. Embedding (penyisipan)

Penyisipan digunakan untuk menyisipkan watermark ke dalam media pembawa (host) yang akan dilindungi. Untuk menyisipkan watermark pada dokumen digital, dibutuhkan suatu algoritma penyisipan. Algoritma penyisipan ini dapat dianalogikan dengan menggunakan 4 variabel $(W, I, K, I w)$ dan setiap variabel merepresentasikan setiap komponen pada proses pemberian watermark. Dimana $I$ adalah media yang belum disisipkan watermark, $W$ adalah watermark yang akan disisipkan, dan $K$ adalah media kunci. Proses $E$ yaitu penyisipan tergantung pada $W$, media pembawa dan kunci sebagai bentuk pengamanannya. Fungsi ini akan menghasilkan Iw yang merupakan media yang telah disisipkan dengan watermark.

Fungsi SVD menjadi tiga matriks $S, U$ dan $V$, lalu matriks $S$ dimodifikasi dengan menyisipkan watermark yang dikalikan suatu nilai konstanta sebagai nilai intensitas dengan rentang 0,1 sampai 1 dengan jarak 0,1. Proses dilanjutkan dengan mengkomposisi matriks $S$ hasil modifikasi lalu digabungkan dengan matriks $U$ dan $V$ dari citra asal. Citra hasil penyisipan watermark disimpan ke dalam file baru (lihat Gambar 1).

$$
\mathrm{A}_{\mathrm{w}}=\mathrm{US}_{\mathrm{w}} \mathrm{V}^{\mathrm{T}}
$$

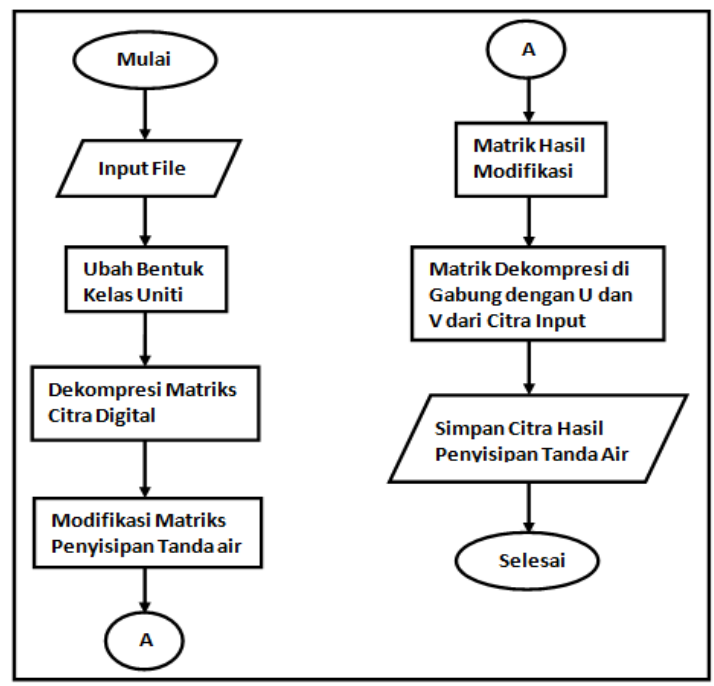

Gambar 1. Skema Proses Penyisipan Tanda Air

\section{b. Extracting (ekstraksi)}

Ekstraksi digunakan untuk mengambil kembali watermark yang telah disisipkan pada media tersebut. Pada skema ekstraksi terdapat variabel baru yaitu $I w$ dan $W$, dimana $I w$ didefinisikan sebagai media yang sudah disisipkan watermark dan $W$ didefinisikan sebagai watermark hasil ekstraksi. Variabel tersebut berbeda dengan variabel pada fungsi penyisipan, karena 
dianalogikan bahwa terdapat kemungkinan $\hat{I} w$ telah dilakukan modifikasi oleh seseorang sehingga watermark $W$ tidak secara tepat sama. Kemudian jika akan dilakukan pengambilan kembali watermark tersebut sebagai bentuk verifikasi, maka digunakan suatu algoritma ekstraksi.

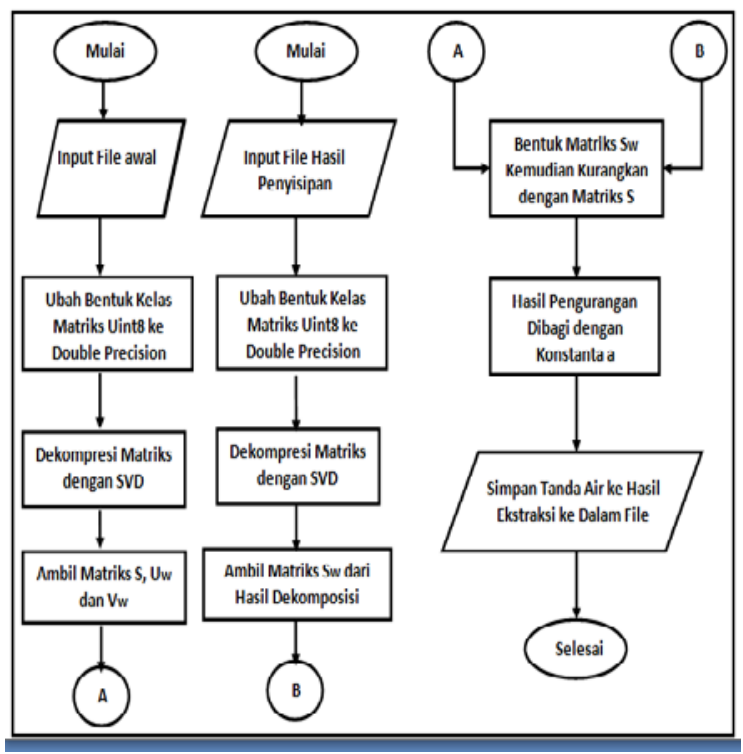

Gambar 2. Skema Proses Ekstraksi Citra Sisipan

Teknik pemberian watermark berbasis komputasi numerik dilakukan secara non-blind, yaitu pada proses ekstraksi membutuhkan komponen dari citra asalnya. Proses ekstraksi watermark dapat dilihat pada Gambar 2.

Langkah pertama adalah memasukkan citra asal dan citra yang telah disisipkan watermark. Proses ekstraksi membutuhkan matriks $S$ dari citra asal untuk mendapatkan matriks $U_{w}$ dan $V_{w}$. Setelah diperoleh matriks $U_{w}$ dan $V_{w}$, kemudian dikalikan dengan matriks $S_{w}{ }^{*}$ yang berasal dari citra yang terwatermark untuk mendapatkan matriks matriks $S^{*}$. Langkah terakhir adalah dengan mengurangi matriks $S^{*}$ dengan matriks $S$ pada citra asli dan membagi dengan nilai intensitasnya. Citra hasil ekstraksi disimpan ke dalam file yang baru. Berikut ini beberapa eksperimen yang dilakukan:

4.1 Hasil Pengujian Metode SVD Terhadap Citra

Tanpa Serangan

Menu penyisipan tanda air digital dapat dilihat pada Gambar 3. Dalam aplikasi ini pengguna dapat memasukkan gambar apapun dalam format *.jpg dan *.png untuk dilakukan penyisipan tanda air citra logo UNIB.

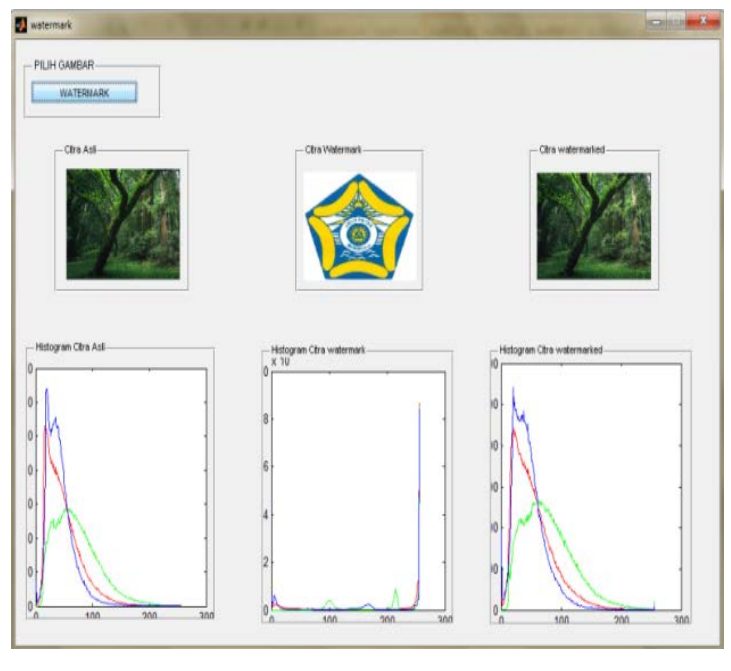

Gambar 3. Aplikasi Penyisipan Tanda Air

Pada Tabel 1. menunjukkan nilai PSNR untuk ketiga kanal R, G, dan B. Nilai PSNR Red tertinggi terdapat pada citra Hutan.jpg yaitu 66,127 dB. Sedangkan Nilai PSNR Red terendah pada nilai PSNR Red citra Babon.png yaitu 45,9585 dB. Nilai PSNR Green tertinggi terdapat pada citra Malena.png yaitu 73,4948. Sedangkan untuk nilai PSNR tertinggi dari Blue terdapat pada citra Cabe.jpg yaitu 59,305.

Pada tabel 2 menunjukkan perbedaan citra masukan dan citra keluaran yang telah disisipi. Citra menjadi lebih cerah dari citra asli hal ini disebabkan karena citra watermark yang disisipkan mempunyai warna lebih cerah atau dominan warna putih, sehingga citra yang disisipi menjadi lebih cerah sebaliknya semakin gelap citra watermark yang disisipkan maka citra hasil watermarked akan

semakin gelap juga. 
Tabel 1. Nilai PSNR citra penyisipan dari citra tanpa serangan

\begin{tabular}{|c|c|c|c|c|}
\hline \multirow[t]{2}{*}{ No. } & \multirow[t]{2}{*}{ Nama File } & \multicolumn{3}{|c|}{$\begin{array}{l}\text { Nilai PSNR Citra Watermarked } \\
(\mathrm{dB})\end{array}$} \\
\hline & & $\mathrm{R}$ & $\mathrm{G}$ & $\mathrm{B}$ \\
\hline 1 & Android.png & 47.593 & 57.6566 & 44.0747 \\
\hline 2 & Babon.png & 45.9585 & 57.9466 & 43.5205 \\
\hline 3 & Cabe.jpg & 56.529 & 83.0734 & 59.305 \\
\hline 4 & Hutan.jpg & 66.127 & 71.6554 & 50.2285 \\
\hline 5 & Koala.jpg & 56.8202 & 64.3279 & 56.9382 \\
\hline 6 & Kolam.jpg & 50.5954 & 61.6827 & 44.677 \\
\hline 7 & Malena.png & 50.9559 & 73.4948 & 54.2987 \\
\hline 8 & Mobil.png & 62.2478 & 72.2974 & 55.2933 \\
\hline 9 & Pantai.jpg & 53.1731 & 71.6443 & 49.3465 \\
\hline 10 & Sawah.jpg & 51.571 & 65.1484 & 46.8777 \\
\hline & Rata-rata & 54,1571 & 67,8928 & 50,4560 \\
\hline
\end{tabular}

Tabel 2. Perbandingan citra asli dan citra pemberian tanda air digital

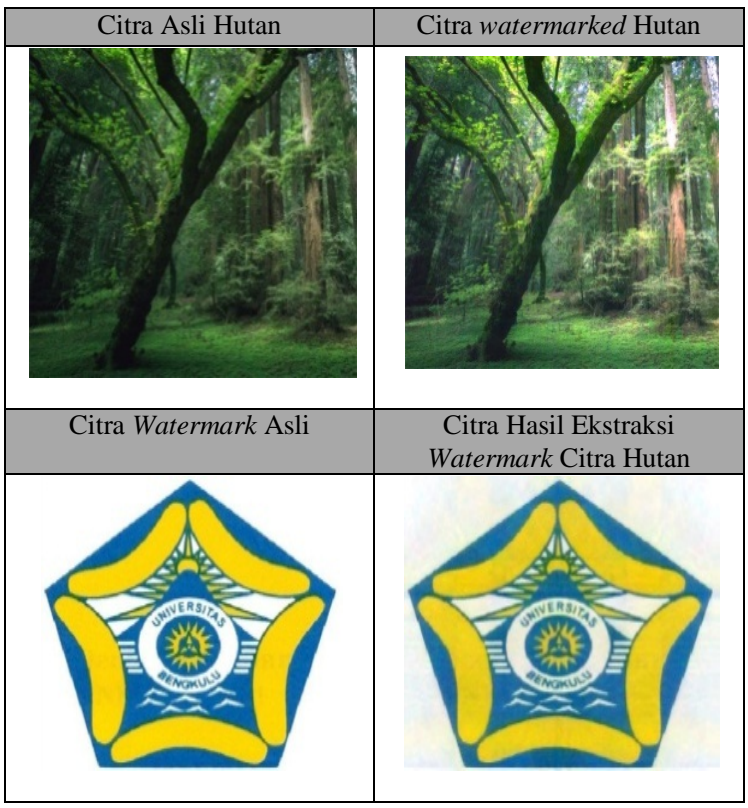

Pada Tabel 3 terdapat nilai PSNR RGB citra hasil ekstraksi watermark. Terlihat dari citra yang diujikan nilai PSNR yaitu citra hasil ekstraksi watermak, perubahan pada nilai PSNR-nya. Hal ini disebabkan oleh perbedaan RGB dari citra asli dan citra watermark. Perubahan pada nilai PSNR mengakibatkan citra berkurang kualitasnya dari citra input. Hal ini disebabkan karena format file dari citra, ukuran file citra, warna dasar citra asli, dan warna dari watermark itu sendiri. Nilai PSNR
Red dan Green tertinggi terdapat pada nilai PSNR dari citra Hutan.jpg yaitu Red $=31,9399$ dB, untuk Green $=33,7467 \mathrm{~dB}$. Sedangkan untuk nilai PSNR Red dan Green terendah terdapat pada citra Kolam.jpg yaitu Red $=29,427$ dB, untuk Green $=$ 29,01 dB. Sehingga dapat diambil kesimpulan bahwa citra hasil ekstraksi Hutan.jpg memiliki kualitas yang paling baik jika dibandingkan dengan citra yang lainnya. Sedangkan citra kualitas paling buruk adalah citra kolam.

Tabel 3. Nilai PSNR citra ekstraksi logo UNIB

\begin{tabular}{|c|l|c|c|c|}
\hline \multirow{2}{*}{ No } & \multirow{2}{*}{ Nama File } & \multicolumn{3}{|c|}{ Nilai PSNR Hasil Ekstraksi } \\
\cline { 3 - 5 } & & $\mathrm{R}$ & $\mathrm{G}$ & $\mathrm{B}$ \\
\hline 1 & Android.png & 30.1453 & 30.0297 & 30.285 \\
\hline 2 & Babon.png & 29.7365 & 29.0103 & 29.9498 \\
\hline 3 & Cabe.jpg & 29.9626 & 30.0982 & 31.9934 \\
\hline 4 & Hutan.jpg & 31.9399 & 33.7467 & 32.4717 \\
\hline 5 & Koala.jpg & 30.1596 & 30.1875 & 30.6079 \\
\hline 6 & Kolam.jpg & 29.427 & 29.01 & 29.7142 \\
\hline 7 & Malena.png & 29.9111 & 31.1971 & 35.6021 \\
\hline 8 & Mobil.png & 30.2404 & 30.1925 & 30.7105 \\
\hline 9 & Pantai.jpg & 30.0363 & 30.0031 & 30.2428 \\
\hline 10 & Sawah.jpg & 30.3303 & 31.8929 & 33.9756 \\
\hline
\end{tabular}

\subsection{Hasil Pengujian Metode SVD Terhadap Citra} dengan Serangan Noise 15\% dan 20\%

Pada Tabel 4 menunjukkan nilai PSNR RGB dari citra hasil ekstraksi watermark dengan serangan Noise $15 \%$ dan $20 \%$. Citra watermark dengan serangan noise $15 \%$ dan $20 \%$ mengalami perubahan nilai PSNR jika dibandingkan dengan tanpa serangan, hal ini disebabkan oleh warna dasar dari citra asli, warna dasar citra ter-watermarked, format file citra, ukuran file citra asli, serta persentase serangan noise yang diberikan terhadap citra tersebut. Dengan serangan noise 15\% menghasilkan nilai PSNR citra hasil ekstraksi lebih tinggi jika dibandingkan dengan citra dengan serangan noise $20 \%$. Sehingga citra hasil ekstraksi 
dengan serangan noise 15\% lebih baik jika terlihat lebih baik jika dibandingkan dengan citra dibandingkan dengan serangan noise $20 \%$.

Tabel 4.Nilai PSNR citra ekstraksi dari citra serangan noise $15 \%$

\begin{tabular}{|c|c|c|c|c|}
\hline \multirow[t]{2}{*}{ No. } & \multirow[t]{2}{*}{ Nama file } & \multicolumn{3}{|c|}{$\begin{array}{c}\text { Nilai PSNR watermark dengan } \\
\text { noise } 15 \%(\mathrm{~dB})\end{array}$} \\
\hline & & $\mathrm{R}$ & G & B \\
\hline 1 & Babon.png & 30.116 & 29.682 & 30.259 \\
\hline 2 & Cabe.jpg & 30.030 & 29.638 & 30.312 \\
\hline 3 & Hutan.jpg & 30.16 & 30.845 & 32.441 \\
\hline 4 & Koala.jpg & 33.613 & 33.370 & 33.446 \\
\hline 5 & Kolam.jpg & 30.243 & 30.450 & 31.151 \\
\hline 6 & Malena.png & 30.039 & 29.750 & 30.422 \\
\hline 7 & Mobil.png & 30.068 & 31.390 & 32.307 \\
\hline 8 & Pantai.jpg & 30.450 & 30.650 & 31.121 \\
\hline 9 & Sawah.jpg & 30.437 & 30.481 & 30.426 \\
\hline 10 & Babon.png & 30.721 & 31.751 & 32.513 \\
\hline \multicolumn{2}{|c|}{ Rata-rata } & 30,588 & 30,801 & 31,440 \\
\hline
\end{tabular}

Tabel 5.Nilai PSNR citra ekstraksi dari citra serangan noise $20 \%$

\begin{tabular}{|c|c|c|c|c|}
\hline \multirow[t]{2}{*}{ No. } & \multirow[t]{2}{*}{ Nama file } & \multicolumn{3}{|c|}{$\begin{array}{c}\text { Nilai PSNR watermark dengan } \\
\text { noise } 20 \%(\mathrm{~dB})\end{array}$} \\
\hline & & $\mathrm{R}$ & G & B \\
\hline 1 & Babon.png & 30.146 & 29.627 & 30.423 \\
\hline 2 & Cabe.jpg & 30.148 & 29.863 & 30.591 \\
\hline 3 & Hutan.jpg & 30.204 & 30.439 & 32.512 \\
\hline 4 & Koala.jpg & 31.695 & 31.301 & 32.467 \\
\hline 5 & Kolam.jpg & 30.252 & 30.189 & 31.001 \\
\hline 6 & Malena.png & 30.225 & 29.907 & 30.714 \\
\hline 7 & Mobil.png & 30.092 & 30.574 & 31.394 \\
\hline 8 & Pantai.jpg & 30.432 & 30.221 & 30.995 \\
\hline 9 & Sawah.jpg & 30.412 & 30.044 & 30.550 \\
\hline 10 & Babon.png & 30.510 & 30.524 & 31.360 \\
\hline \multicolumn{2}{|c|}{ Rata-rata } & 30,412 & 30,269 & 31,201 \\
\hline
\end{tabular}

Tabel 6 Perbandingan citra hasil ekstraksi serangan noise 15\% dan $20 \%$

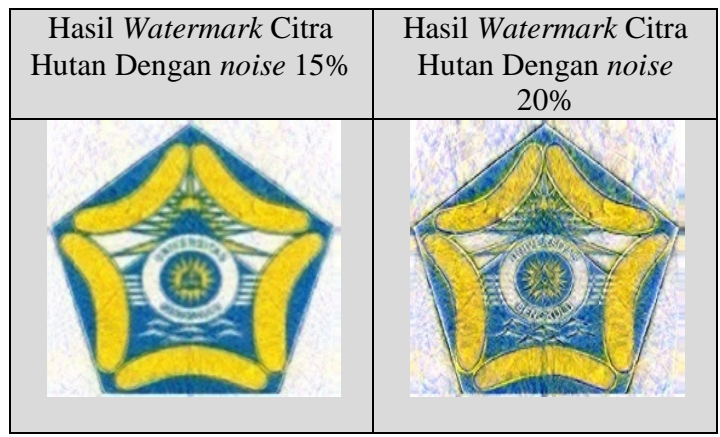

Pada Tabel 5, Tabel 6, dan Tabel 7 terlihat perbedaan antara citra ekstraksi dengan noise 15\% dengan noise 20\%. Artinya persentase dari noise yang diberikan di citra mempengaruhi hasil dari ekstraksi citra tersebut.

4.3 Hasil Pengujian Metode SVD Terhadap Citra dengan Serangan Kompresi file 5\%, 15\%, dan $25 \%$

Pada Tabel 7 terdapat nilai PSNR RGB dari citra ekstraksi dengan serangan kompresi $5 \%$. Citra yang mendapatkan serangan kompresi 5\% menurun kualitas citranya. Rata-rata nilai PSNR RGB dari citra tersebut lebih kecil dari citra tanpa serangan. Dengan kata lain citra tersebut memiliki kualitas citra yang menurun dari citratanpa serangan.

Tabel 7. Nilai PSNR citra ekstraksi dengan serangan kompresi file $5 \%$

\begin{tabular}{|c|c|c|c|c|c|}
\hline \multirow[t]{2}{*}{ No } & \multirow[t]{2}{*}{ Nama file } & \multirow[t]{2}{*}{$\begin{array}{l}\text { Ukuran } \\
\text { Gambar } \\
\text { (kb) }\end{array}$} & \multicolumn{3}{|c|}{$\begin{array}{c}\text { Nilai PSNR Ekstraksi } \\
\text { dengan Serangan } \\
\text { (dB) }\end{array}$} \\
\hline & & & $\mathrm{R}$ & G & B \\
\hline 1 & Babon.png & 27,5 & 29.97 & 29.66 & 30.03 \\
\hline 2 & Cabe.jpg & 16,6 & 30.00 & 29.99 & 32.19 \\
\hline 3 & Hutan.jpg & 20,8 & 30.95 & 31.67 & 32.97 \\
\hline 4 & Koala.jpg & 25 & 30.16 & 30.08 & 30.37 \\
\hline 5 & Kolam.jpg & 20,7 & 29.52 & 28.86 & 29.68 \\
\hline 6 & Malena.png & 17,6 & 29.87 & 30.22 & 30.88 \\
\hline 7 & Mobil.png & 31,5 & 30.22 & 30.11 & 30.46 \\
\hline 8 & Pantai.jpg & 22,4 & 30.17 & 29.71 & 30.11 \\
\hline 9 & Sawah.jpg & 14,5 & 30.29 & 30.52 & 32.25 \\
\hline \multicolumn{3}{|c|}{ Rata-rata } & 30,13 & 30,09 & 30,99 \\
\hline
\end{tabular}

Pada Tabel 8 terlihat nilai PSNR citra ekstraksi dengan serangan kompresi 15\%. Citra yang mendapat serangan kompresi $15 \%$ mengalami penurunan nilai PSNR citra hasil ekstraksinya jika dibandingkan dengan citra tanpa serangan maupun dengan kompresi 5\%. Pada saat dilakukan ekstraksi watermark dari citra tersebut terlihat lebih pekat jika dibandingkan dengan citra 
ekstraksi tanpa serangan maupun dengan serangan kompresi 5\%.

Tabel 8. Nilai PSNR citra ekstraksi dengan serangan kompresi file $15 \%$

\begin{tabular}{|c|c|c|c|c|c|}
\hline \multirow[t]{2}{*}{ No } & \multirow{2}{*}{$\begin{array}{l}\text { Nama } \\
\text { Gambar }\end{array}$} & \multirow{2}{*}{$\begin{array}{c}\text { Ukuran } \\
\text { Gambar } \\
\text { (kb) }\end{array}$} & \multicolumn{3}{|c|}{$\begin{array}{l}\text { Nilai PSNR Ekstraksi } \\
\text { dengan Serangan (dB) }\end{array}$} \\
\hline & & & $\bar{R}$ & G & $\mathrm{B}$ \\
\hline 1 & Cabe.jpg & 20,8 & 29.94 & 29.94 & 31.96 \\
\hline 2 & Hutan.jpg & 35,4 & 30.76 & 31.34 & 32.32 \\
\hline 3 & Sawah.jpg & 21,9 & 30.28 & 30.50 & 32.41 \\
\hline 4 & Kolam.jpg & 32 & 29.41 & 28.85 & 29.64 \\
\hline 5 & Koala.jpg & 36,9 & 30.14 & 30.06 & 30.42 \\
\hline 6 & Kelapa.jpg & 31,8 & 30.12 & 29.73 & 30.08 \\
\hline 7 & Malena.png & 23,3 & 29.83 & 30.23 & 31.00 \\
\hline 8 & Babon.png & $40 ., 3$ & 29.89 & 29.50 & 29.97 \\
\hline \multicolumn{3}{|c|}{ Rata-rata } & 30,05 & 30,02 & 30,97 \\
\hline
\end{tabular}

Pada Tabel 9 terlihat nilai PSNR citra ekstraksi dengan serangan kompresi 25\%. Citra yang mendapat serangan kompresi 25\% mengalami penurunan kualitas citra hasil ekstraksinya jika dibandingkan dengan citra tanpa serangan maupun dengan kompresi 5\% dan 15\%. Hal ini dapat dilihat dengan berkurangnya nilai PSNR dari hasil ekstraksi citra dengan serangan kompresi 25\%. Pada saat dilakukan ekstraksi watermark dari citra tersebut terlihat lebih pekat dibandingkan dengan citra tanpa serangan maupun dengan serangan kompresi 5\% dan 15\%. Sehingga dapat disimpulkan bahwa citra dengan serangan kompresi 25\% kurang baik kualitas ekstraksinya jika dibandingkan dengan citra hasil ekstraksi yang diserang dengan kompresi 5\% dan 15\%.

Tabel 9. Nilai PSNR citra ekstraksi dengan serangan kompresi file $25 \%$

\begin{tabular}{|r|l|l|c|c|c|}
\hline \multirow{2}{*}{ No } & \multirow{2}{*}{$\begin{array}{c}\text { Nama } \\
\text { Gambar }\end{array}$} & $\begin{array}{c}\text { Ukuran } \\
\text { Gambar }\end{array}$ & \multicolumn{3}{|c|}{$\begin{array}{c}\text { Nilai PSNR Ekstraksi } \\
\text { dengan Serangan (dB) }\end{array}$} \\
\cline { 4 - 6 } & & $\mathrm{R}$ & $\mathrm{G}$ & $\mathrm{B}$ \\
\hline 1 & Cabe.jpg & 24,2 & 29.9431 & 29.9289 & 32.0087 \\
\hline 2 & Hutan.jpg & 53,1 & $\mathbf{3 0 . 6 8 7 5}$ & $\mathbf{3 1 . 0 8 6 9}$ & $\mathbf{3 2 . 3 4 4 6}$ \\
\hline 3 & Sawah.jpg & 28,3 & 30.2801 & 30.5038 & 32.302 \\
\hline 5 & Koala.jpg & 49 & 30.1368 & 30.0628 & 30.4196 \\
\hline 7 & Malena.png & 29,2 & $\mathbf{2 9 . 8 3 4 9}$ & 30.2291 & 30.9827 \\
\hline 8 & Mobil.png & 19,2 & 30.227 & 30.0992 & 30.4809 \\
\hline 9 & Babon.png & 52,6 & 29.8816 & $\mathbf{2 9 . 4 8 5 5}$ & $\mathbf{2 9 . 9 6 0 7}$ \\
\hline
\end{tabular}

Pada tabel 9 dan Tabel 10 terlihat citra hasil ekstraksi dengan serangan kompresi yang berbeda. Jika dibedakan dengan hanya melihat ketiga citra tersebut tampak tidak ada perbedaan akan tetapi jika dibandingkan dengan menghitung nilai PSNRnya maka citra dengan kompresi 5\% lebih baik dibandingkan dengan citra kompresi 15\% dan $25 \%$.

Tabel 10. Perbandingan citra ekstraksi serangan kompresi 5\%,15\%,dan 25\%

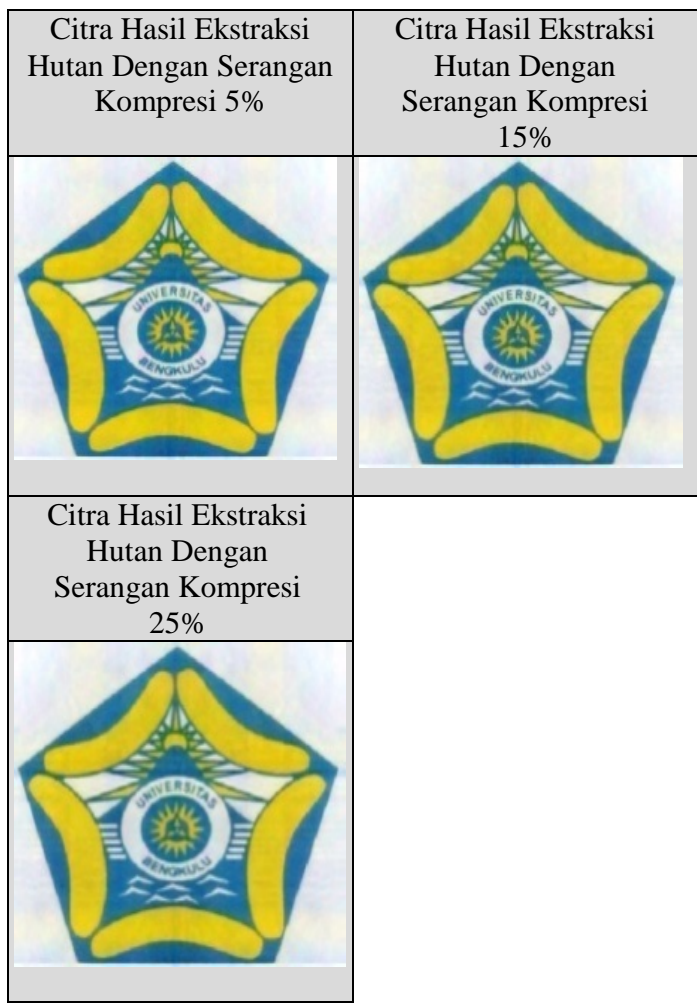

4.4 Hasil Pengujian Metode SVD Terhadap Citra dengan Serangan Gausian Blur (Radius 2 dan 3 Piksel)

Pengujian berikutnya adalah pengujian black box terhadap metode SVD dengan menggunakan citra 512x512 piksel dengan serangan Gaussian Blur (Radius 2 dan 3 piksel). Berikut tabel 11 dan Tabel 12 menunjukkan hasil nilai PSNR dari percobaannya. 
Tabel 11. Nilai PSNR citra ekstraksi dengan serangan Gaussian Blur dengan radius 2 piksel

\begin{tabular}{|l|l|c|c|c|}
\hline \multirow{2}{*}{ No. } & \multirow{2}{*}{ Nama File } & \multicolumn{3}{|c|}{$\begin{array}{r}\text { Nilai PSNR Ekstraksi } \\
\text { Serangan Gausian Blur } \\
\text { (Radius 2 Piksel) (dB) }\end{array}$} \\
\cline { 3 - 5 } & & $\mathrm{R}$ & $\mathrm{G}$ & $\mathrm{B}$ \\
\hline 1 & Android.png & 30.08 & 29.92 & 30.17 \\
\hline 2 & Babon.png & 29.74 & 29.10 & 30.10 \\
\hline 3 & Cabe.jpg & 30.01 & 32.49 & 32.83 \\
\hline 4 & Hutan.jpg & 45.04 & 45.89 & 40.57 \\
\hline 5 & Koala.jpg & 30.38 & 31.86 & 33.31 \\
\hline 6 & Kolam.jpg & 29.73 & 29.51 & 30.00 \\
\hline 7 & Malena.png & 30.58 & 47.97 & 42.77 \\
\hline 8 & Mobil.png & 30.68 & 31.30 & 31.50 \\
\hline 9 & Pantai.jpg & 30.79 & 50.18 & 30.43 \\
\hline 10 & Sawah.jpg & 31.41 & 39.27 & 37.67 \\
\hline & Rata-Rata & $\mathbf{3 1 , 8 4}$ & $\mathbf{3 6 , 7 5}$ & $\mathbf{3 3 , 9 3}$ \\
\hline
\end{tabular}

Tabel 12. Nilai PSNR citra ekstraksi dengan serangan Gaussian Blur dengan radius 3 piksel

\begin{tabular}{|l|l|c|c|c|}
\hline \multirow{2}{*}{ No. } & \multirow{2}{*}{ Nama File } & \multicolumn{3}{|c|}{$\begin{array}{r}\text { Nilai PSNR Ekstraksi } \\
\text { Serangan Gausian Blur } \\
\text { (Radius 3 Piksel) (dB) }\end{array}$} \\
\cline { 3 - 5 } & & $\mathrm{R}$ & $\mathrm{G}$ & $\mathrm{B}$ \\
\hline 1 & Android.png & 30.06 & 29.88 & 30.14 \\
\hline 2 & Babon.png & 29.75 & 29.10 & 30.12 \\
\hline 3 & Cabe.jpg & 30.00 & 32.72 & 33.57 \\
\hline 4 & Hutan.jpg & 44.96 & 45.65 & 42.48 \\
\hline 5 & Koala.jpg & 30.51 & 32.71 & 34.81 \\
\hline 6 & Kolam.jpg & 29.74 & 29.53 & 30.02 \\
\hline 7 & Malena.png & 30.78 & 50.55 & 44.32 \\
\hline 8 & Mobil.png & 30.95 & 31.76 & 31.81 \\
\hline 9 & Pantai.jpg & 31.07 & 50.91 & 30.42 \\
\hline 10 & Sawah.jpg & 32.30 & 40.86 & 38.63 \\
\hline & Rata-Rata & $\mathbf{3 2 , 0 1}$ & $\mathbf{3 7 , 3 7}$ & $\mathbf{3 4 , 6 3}$ \\
\hline
\end{tabular}

Pada Tabel 12 dan Tabel 13 terdapat nilai PSNR RGB dari citra dengan serangan Gaussian Blur. Citra yang mendapatkan serangan blur ( radius 3 piksel ) mempunyai nilai PSNR RGB ratarata lebih tinggi jika dibandingkan dengan citra serangan blur (radius 2 piksel). Perubahan hasil ekstraksi dari citra dipengaruhi oleh tingkatan blur yang diberikan terhadap citra yang diujikan
Tabel 13. Perbandingan citra ekstraksi serangan Gausian Blur

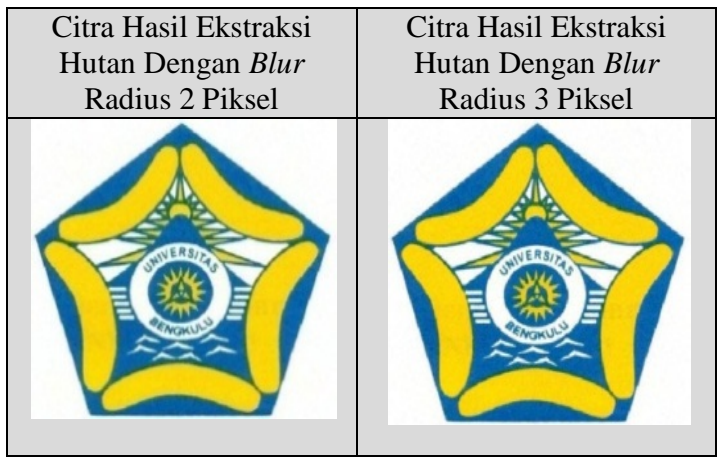

Pada tabel 13 terlihat bahwa citra dengan serangan blur radius 2 piksel lebih baik dibandingkan dengan citra dengan serangan blur radius 3 piksel.

\section{KESIMPULAN DAN SARAN}

Berdasarkan analisa perancangan sistem, implementasi dan pengujian sistem, maka dapat disimpulkan bahwa :

1) Metode Singular Value Decomposition yang diimplementasikan pada aplikasi ini memberikan hasil yang optimal untuk penyisipan dan ekstraksi watermark pada citra digital baik dengan serangan maupun tanpa serangan.

2) Aplikasi mampu mendeteksi watermark dari citra ter-watermarked yang mendapat serangan noise. Dari hasil percobaan dengan serangan noise 15\% menghasilkan citra hasil ekstraksi lebih baik dibandingkan dengan serangan noise $20 \%$.

3) Aplikasi mampu mendeteksi watermark dari citra ter-watermarked yang mendapat serangan Gausian blur. Dari hasil percobaan dengan serangan blur (radius 3 piksel) menghasilkan citra hasil ekstraksi lebih baik dibandingkan dengan serangan blur (radius 2 piksel).

4) Aplikasi mampu mendeteksi watermark dari citra ter-watermarked yang mendapat serangan kompresi file. Citra dengan serangan kompresi 
5\% menghasilkan citra hasil ekstraksi lebih

baik dibandingkan dengan serangan kompresi $15 \%$, dan $25 \%$

Untuk pengembangan penelitian selanjutnya, saran yang dapat diberikan, yaitu:

1) Mengembangkan aplikasi watermarking ini dengan menambahkan pengujian dengan serangan yang lebih banyak untuk mengidentifikasi watermark, misalnya terhadap berbagai jenis noise, citra dengan penimpaan ganda watermark, dan sebagainya.

2) Aplikasi ini hanya menguji citra dengan format *.JPG dan *.PNG, sehingga di masa depan baiknya pengujian dilakukan dengan lebih banyak format file.

\section{REFERENS}

[1] Nurlailah, Siti. Aplikasi Fragile Watermarking untuk Melindungi Keaslian Foto. Universitas Syarif Hidayatullah. Jakarta. 2010

[2] Mulaab. Teknik Watermaking Dalam Domain Wavelet Untuk Proteksi Kepemilikan Pada Data Citra Medis. Jurnal Trunojoyo.Universitas Trunojoyo. Madura. 2011.

[3] Tyas, Lia Ayuning. Watermarking Citra Digital Berbasis DWT-SVD Dengan Detektor Non-Blind. Universitas Diponegoro. Semarang. 2009.

[4] Basaruddin, T. Studi Skema Pemberian Tanda Air Video Digital Berbasis DWT-SVD dengan Detektor SEMI-BLIND. Jurnal Makara. Universitas Indonesia. Jakarta. 2009.

[5] Utari, Suci. Implementasi Watermarking Citra Digital menggunakan DB4 dan SVD. Sekolah Tinggi Teknologi (STT) PLN. Jakarta. 2007.

[6] Doleres. Pengantar Matlab 6. PT. Indeks Kelompok. Jakarta. 2003.

[7] Putra, Darma. Pengolahan Citra Digital. Penerbit Andi. Yogyakarta 2010. 